\title{
Geochemical and tectonic significance of Arbat alkali gabbro-monzonite-syenite intrusions, Urumieh-Dokhtar Magmatic Arc, Iran
}

\author{
Abdolnaser FAZLNIA ${ }^{1, *}$ \\ 1 Urmia University, Department of Geology, 57153-165 Urmia, Islamic Republic of Iran
}

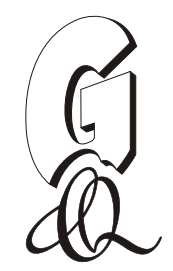

FazInia, A., 2019. Geochemical and tectonic significance of Arbat alkali gabbro-monzonite-syenite intrusions, Urumieh-Dokhtar Magmatic Arc, Iran. Geological Quarterly, 63 (1): 16-29, doi: 10.7306/gq.1449

Associate editor: Tomasz Bajda

The Oligocene Arbat alkali intrusions of the Eastern Miandoab are located in the northwestern part of Iran and belong to the Urumieh-Dokhtar Magmatic Arc (UDMA). The intrusions show a ring structure with gabbro-monzogabbro-monzodiorite (mafic units) on the edges, with monzonite-monzosyenite-syenite (felsic units) gradually going towards the central parts. The textures in different rock types are cumulate, granular and laminated. The high values of $(\mathrm{La} / \mathrm{Sm})_{n}$ and $(\mathrm{La} / \mathrm{Yb})_{n}$ contents of $\mathrm{K}, \mathrm{Rb}$ and $\mathrm{Cs}$ (positive anomalies normalized on the basis of the primitive mantle), low concentrations of $\mathrm{Hf}, \mathrm{Nb}, \mathrm{Zr}$ and $\mathrm{Ta}$ (negative anomalies), and the changes in $\mathrm{Th} / \mathrm{Nb}, \mathrm{Th} / \mathrm{Ta}, \mathrm{La} / \mathrm{Nb}$ and $\mathrm{Ce} / \mathrm{Pb}$ ratios along with the geochemical and tectonic setting evidence exhibit a subduction-modified mantle origin for the formation of these rocks. Accordingly, the intrusions were formed between the Central Iran and the Arabian plates as a result of the partial melting of a mantle wedge at a syn-collision or post-collision arc-related environment. Our data suggested that, after the end of the oblique Neotethys subduction and during/after the continental collision, the break-off or rollback of the Neotethys slab beneath western Iran, in the Oligocene, might have occurred. Such a process led to the change in the geothermal gradient of the mantle wedge because of the subduction fluids, transtension, pressure reduction along the SE-trending lateral depth strike-slip fault zones in the upper part of the mantle wedge, decompression partial melting at the mantle, and the resulting formation of a mafic potassium-rich melt. The mafic magma was injected into crustal magma chambers; probably, the fractional crystallization and partial contamination occurred with crustal components, forming the intermediate and felsic rocks in the intrusions. Geochemical evidence related to the variations in the ratios of $\mathrm{Th} / \mathrm{Yb}, \mathrm{Ta} / \mathrm{Yb}, \mathrm{Rb} / \mathrm{Y}$, and $\mathrm{Nb} / \mathrm{Y}$ and Harker variation diagrams along with the spider diagrams confirmed fractional crystallization and partial FC (fractional crystallization) and AFC (assimilation and fractional crystallization) in the intrusions.

Key words: gabbro-monzonite-syenite complex, geochemistry, collisional zone, Neotethys subduction.

\section{INTRODUCTION}

Many syenite-monzonite rocks are associated with gabbro, diorite, monzogabbro, monzodiorite and appinite rocks, and are metaluminous to peralkaline in terms of their composition (Murphy, 2013; Haldar and Tišljar, 2014). In many cases, they are also commonly associated with granites (Gill, 2010). Syenites often occur in extensional settings in association with peralkaline A-type granitoids (anorogenic), monzonites, and alkaline or tholeiitic diorite-gabbro (e.g., monzogabbro). These environments are associated with the continental rifts (e.g., Green, 1992; Upton et al., 1996; Upton et al., 2003), hot spots (e.g., Upton et al., 2003; Bailey et al., 2006; Kogarko et al., 2006), back-arc tensional basins, subduction-related settings (e.g., Beard and Borgia, 1989; Bacon et al., 2007; Fazlnia and

\footnotetext{
*E-mail: a.fazlnia@urmia.ac.ir and nfazlnia@yahoo.com
}

Received: July 8, 2018; accepted: October 23, 2018; first published online: January 18, 2019
Alizade, 2013; Murphy, 2013; Fazlnia, 2017), and continental syn- or post-collision zones (Gualda and Vlach, 2007; Gill, 2010; Aghazadeh et al., 2010; Castro et al., 2013; Moreno et al., 2014, 2016). Geographical areas, in which syenite-monzonite-gabbro complexes occur, include lopolith intrusions (Kogarko et al., 2006), continental rift intrusions (Green, 1992; Upton et al., 1996, 2003), and subduction-related assemblages (Arculus and Wills, 1980; Conrad and Kay, 1984; Beard and Borgia, 1989; Bacon et al., 2007).

In Iran, major plutonic outcrops associated with the Zagros orogenic belt have been formed during Mesozoic and Tertiary times (Berberian and King, 1981; Alavi, 1994). The Zagros orogenic belt, which is considered part of the Alpine orogenic system, consists of three parallel zones with the NW-SE trend. These zones include (1) the Zagros Fold-Thrust Belt, (2) the Sanandaj-Sirjan Zone, and (3) the Urumieh-Dokhtar Magmatic Arc (UDMA; Alavi, 1994; Fig. 1). All three zones extend to the north-west of Iran.

Petrological studies in northwestern Iran have indicated that syenite-monzonite-gabbro assemblages might have been created in the supra-subduction zone (Aghazadeh et al., 2010) and/or post-collision settings (gabbroic-syenitic-monzonitic in- 


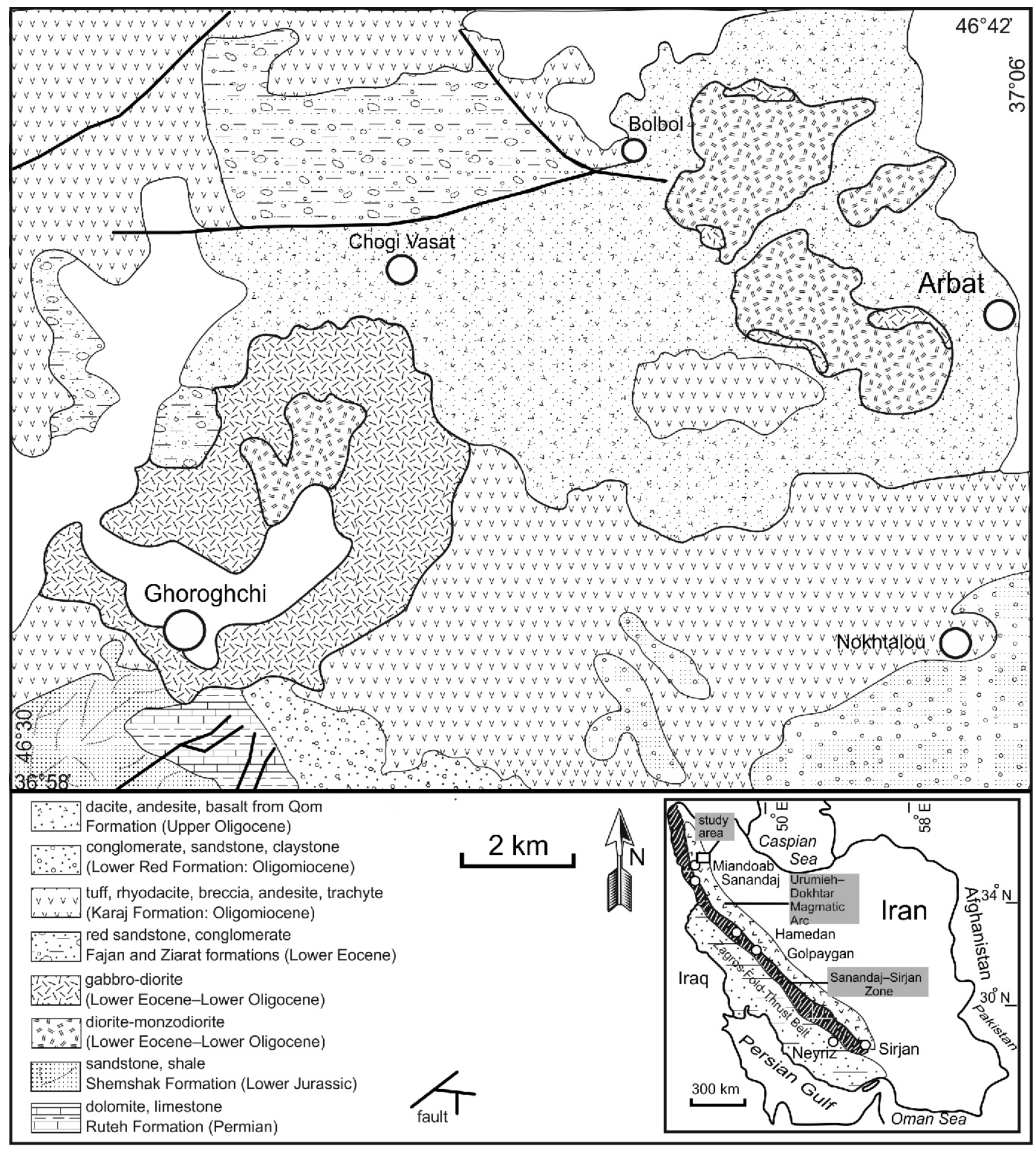

Fig. 1. Simplified geological map of eastern Miandoab (modified after Rezaei et al., 2009); the bottom right of the figure is a simplified map of Iran and locations of the Urumieh-Dokhtar Magmatic Arc and Sanandaj-Sirjan Zone (modified after Stöcklin, 1968) 
trusions from the Alborz magmatic belt, NW Iran; Castro et al., 2013). Therefore, the alkali rocks, such as syenitemonzonite-gabbro assemblages in the north-west of Iran, were formed during the final stages of the Neotethys subduction beneath Central Iran. In addition to the alkali intrusive rocks, alkali volcanic rocks, such as trachytes, trachybasalts and basalts of the same ages, have been found throughout northwestern Iran (Kheirkhah et al., 2009; Azizi et al., 2014). These rocks are also associated with the last stages of the Neotethys subduction beneath Central Iran, or with syn- to post-collision environments between the Arabian and Central Iran plates.

The Arbat syenite-monzonite-gabbro complex, in the Eastern Miandoab from the northern UDMA of Iran, comprises part of the rocks exposed in the Zagros orogenic belt. This study investigated the geochemical and tectonic setting of the rocks. The study of these rocks could help to reconstruct the last stages of the Neotethys subduction in the northwestern region of the UDMA, Iran. The study area could be of great interest for the Alpino-Himalayan orogenic belt. The study of these rocks could also help to understand the old tectonic environment in the central parts of the belt.

\section{GEOLOGICAL SETTING AND FIELD OBSERVATIONS}

The UDMA is a subduction-related Andean-type magmatic arc composed of tholeiitic, calc-alkaline, and K-rich alkaline intrusive and extrusive rocks, along with an active margin of the Iranian Plate, located between the Sanandaj-Sirjan and Central Iran zones (Alavi, 1994; Shahabpour, 2007). The mentioned lithology is a result of the Neotethys subduction beneath Central Iran (Berberian and King, 1981). The oldest rocks in the UDMA are calc-alkaline intrusive rocks that cut across the Upper Jurassic formations and are overlain unconformably by the Lower Cretaceous fossiliferous limestone. The Eocene Urumieh-Dokhtar Magmatic Arc contains abundant mafic to intermediate volcanic and intrusive rocks, with calc-alkaline to shoshonitic chemistry (Berberian and King, 1981; Alavi, 1994; Yeganehfar et al., 2013; Jafari et al., 2015; Hassanzadeh and Wernicke, 2016; Babazadeh et al., 2017; Jafari et al., 2018; Fazlnia, 2018a). The youngest rocks in the UDMA consist mostly of lava flows and pyroclastics that belong to the Pliocene to Quaternary volcanic zones of adakite, alkaline and calc-alkaline composition (Berberian and Berberian, 1981; McInnes et al., 2003; Jahangiri, 2007; Omrani et al., 2008; Neill et al., 2013, 2015; Rasouli et al., 2016). All these formations are related to the subduction of the northern Neotethys (Nabavi, 1976). In contrast, Kheirkhah et al. (2009), Allen et al. (2013), McQuarrie and van Hinsbergen (2013), and Azizi et al. (2014) have concluded that the youngest rocks in the UDMA were formed at the end of subduction. The Arbat intrusions are located $25 \mathrm{~km}$ east of Miandoab and in the north of UDMA (Fig. 1), according to the structural divisions of Stöcklin (1968).

Eocene-Oligocene syenites and the associated rocks from UDMA and north-west Central Iran have been studied (Ashrafi et al., 2009; Ferdowsi et al., 2015). These rocks are saturated or undersaturated in silica. Intrusions from the northwestern part of UDMA, NW Iran, are Si-saturated and undersaturated, and are alkaline-shoshonitic in terms of their composition (Ashrafi et al., 2009; Tajbakhsh et al., 2012; Ferdowsi et al., 2015). These rocks occurred in a syn- or post-collision arc-related setting, during the Neotethys closure and the final evolution of the Zagros Orogeny.
Various studies (Aghazadeh et al., 2010; Castro et al., 2013) of granite-syenite-monzonite-gabbro intrusions from NW Iran (northern UDMA), Late Eocene-Oligocene in age, and from the western Alborz magmatic belt (a part of the Zagros orogen) indicate that these rocks show saturated-under saturated shoshonitic and adakitic characteristics. These rocks were derived by the melting of a metasomatized mantle in a post-collision arc-related setting that resulted from the Neotethys closure during the final evolution of the Zagros Orogeny.

Some Late Eocene to Late Miocene alkaline and shoshonitic outcrops in the NW part of UDMA have been expanded into lava flows and dykes with the compositions of micro-monzonite, micro-syenite, lamprophyre, basanite, and foid-bearing rocks in NW Iran (Moayyed et al., 2008; Ashrafi et al., 2009; Shafaii Moghadam et al., 2014; Aghazadeh and Badrzadeh, 2015). These researchers indicated that the rocks were formed in a post-collision arc setting related to a continental collision between Central Iran and the Arabian plates.

The Arbat intrusions from the eastern part of Miandoab (Fig. 1) are mostly monzonitic and monzosyenitic rocks along with mafic parts, such as monzogabbro and monzodiorite, and with felsic parts, like alkali syenite (Fig. 2). This area is part of UDMA, based on the structural-sedimentary divisions of Iran (Stöcklin, 1968). The Arbat intrusions are located in the southern and southwestern parts of the previously studied syenites and the related rocks from the northwestern UDMA (Ashrafi et al., 2009; Aghazadeh et al., 2010; Castro et al., 2013; Ferdowsi et al., 2015). In addition, these rocks are located $100 \mathrm{~km}$ to the south-east of the Islami (Saray) Peninsula (Shafaii Moghadam et al., 2014). They suggested that the Late Miocene Saray high-K magmas were derived to a small degree from partial melting of the subduction-metasomatized (subcontinental) lithospheric mantle source in a post-collisional setting.

The study of igneous intrusions into the Cretaceous limestone, shale and regional metamorphic rocks can be of interest. Around the village of Arbat (Fig. 1), all types of igneous rocks have intruded into the Eocene Fajan and Ziarat formations. These intrusions metamorphosed the formations and were covered by the Oligo-Miocene formations (Rezaei et al., 2009). The fragments of Eocene volcanic rocks can be seen in the form of metamorphosed xenoliths (hornfels) within these intrusions. Therefore, the age of all study rocks could be between Early to Late Oligocene. However, Rezaei et al. (2009) offered the Oligocene age for these rocks.

Many studied outcrops are observed in the erosional and mound formed sets (Fig. 2A-C). Some parts of the mafic and felsic outcrops have been exposed in a rubble form of different sizes (Fig. 2B, C) as a result of the onion-skin weathering. All rock types are coarse-grained and some crystals are more than $3 \mathrm{~cm}$ in size (Fig. 2A, bottom right, 2E). Fresh outcrops of the mafic rocks are seen in grey (Fig. 2D). The mafic and felsic parts have normal contact (Fig. 2A) and the existence of the rounded fine-grained, more mafic cognate enclaves from the early stages of crystallization in the magma chamber inside the felsic parts (2E, bottom right) show two different crystalline accumulations. These enclaves were formed at the initial pluses of magma injection; they have been surrounded by the subsequent pluses of magma injection (Didier and Barbarian, 1991). In addition, they may be the result of two distinct magma types (e.g., one crustal, and one mantle-derived; see the discussion section). Coarse-grained dikes with a small thickness from a few centimetres to 10 centimetres of felsic parts inside mafic parts and of mafic parts inside felsic part (Fig. 2E) indicate that 

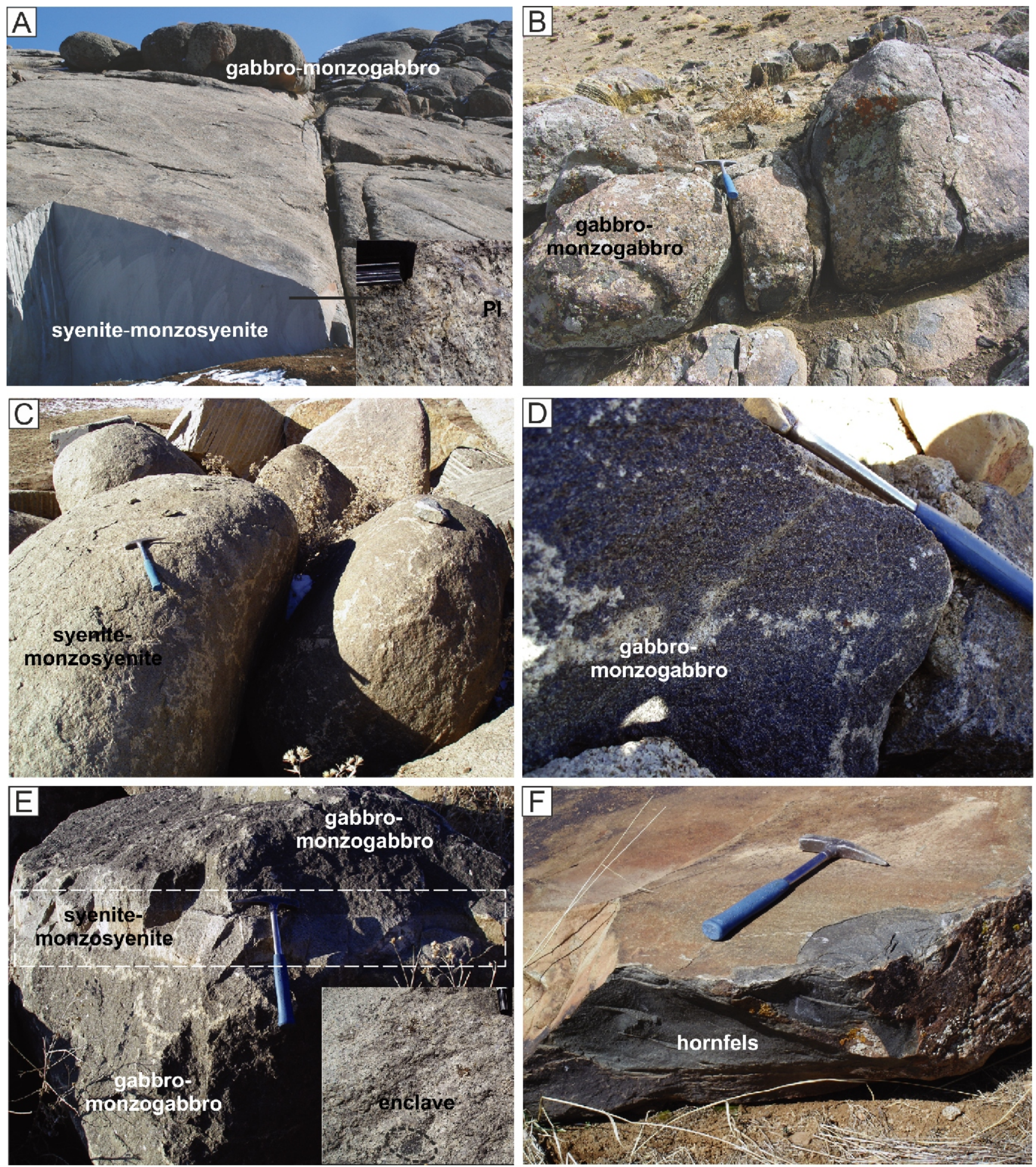

Fig. 2. Field observations of mafic to felsic alkaline intrusions from the east of Miandoab

A - common syenite to gabbro outcrops; B, C - syenite and gabbro turned to cobbles due to onion-skin weathering; $\mathbf{D}$ - thick and coarse-grained intrusions of gabbro and monzogabbro; $\mathbf{E}$ - coarse-grained syenite-monzonite dikes ins gabbro and monzogabbro, mafic microgranular enclaves from the mafic parts in the felsic parts are shown in bottom right; $\mathbf{F}$ - fragments of Eocene volcanic rocks in the form of hornfels within the intrusions 
all types of the rocks are of the same age. The observation of the fragments of the Eocene volcanic rocks with the hornfels structure (Fig. 2F) inside the Arbat intrusions indicates the penetration of these masses in the Eocene rocks.

\section{PETROGRAPHIC OBSERVATIONS}

The syenites are generally coarse-grained (the average grain size is $4 \mathrm{~mm}$ ) and composed mainly of alkali feldspar (80-100 vol.\%) with the variable development of perthitic intergrowth textures, plagioclase (0-10 vol.\%), and biotite and opaque minerals ( $0-5$ vol. \%; Fig. 3A). The rocks have mostly granular and laminated textures, and long perthitic intergrowth alkali feldspars occur with the sutured boundaries. There are no magmatic initial-hydrous minerals, such as amphibole and biotite, in these rocks.

The monzonites are generally medium-grained (with the average grain size of $0.6 \mathrm{~mm}$ ); they are composed mainly of alkali feldspar (40-60 vol.\%), plagioclase (20-45 vol.\%), biotite (5-20 vol.\%), clinopyroxene (2-5 vol.\%), and opaque minerals (2-5 vol.\%). Accessory apatite and sometimes titanite occur with small abundances (Fig. 3B). The rocks have primarily a granular texture. Laminated textures and long perthitic intergrowth alkali feldspars also occur in the rocks.

The mafic facies (Fig. 2A, B, D, E) are mostly composed of gabbro, monzogabbro and monzodiorite. The rocks are generally medium-grained (the average grain size is $0.7 \mathrm{~mm}$ ). They are composed mainly of plagioclase (25-45 vol.\%), alkali feldspar (5-15 vol.\%), biotite (5-15 vol.\%), olivine (5-20 vol.\%), clinopyroxene (10-30 vol.\%), and opaque minerals (5-15 vol.\%) along with small abundances of apatite and titanite (Fig. 3C, D). In some of these rocks, biotite crystals fill the spaces between the grains (Fig. 3D). Euhedral fine-grained apatite crystals occur within the biotite. Their texture varies from granular to cumulate and intercumulate; however, in some places, a poikilitic texture, in which relatively large crystals of biotite enclose numerous smaller crystals of olivine, clinopyroxene and plagioclase, is observed (Fig. 3C, D). Most of the cognate enclaves (Fig. 2E) are of monzonitemonzodiorite composition. With a sharp boundary, they are finer-grained than their host rocks. The enclaves occur in syenites and monzonites.

\section{WHOLE-ROCK GEOCHEMISTRY}

\section{ANALYTICAL METHODS}

Whole-rock samples (22) were dried at $60^{\circ} \mathrm{C}$ and sieved to 80 mesh. They were jaw-crushed to $70 \%$ passing 10 mesh ( $2 \mathrm{~mm}$ ), of which $250 \mathrm{~g}$ aliquots were pulverized to $95 \%$ passing 150 mesh $(100 \mathrm{~mm})$ in a mild steel ring and puck mill. The chemical compositions of the samples were determined at the GeoLab and ACME Analytical Laboratories Ltd., Vancouver, Canada. Aliquots of the $0.2 \mathrm{~g}$ sample material were weighed into a graphite crucible and mixed with $1.5 \mathrm{~g}$ of $\mathrm{LiBO}_{2} / \mathrm{Li}_{2} \mathrm{~B}_{4} \mathrm{O}_{7}$ flux. The flux/sample charge was heated in a muffle furnace for $30 \mathrm{~min}$ at $980^{\circ} \mathrm{C}$. The cooled bead was dissolved in $100 \mathrm{ml}$ of $5 \% \mathrm{HNO}_{3}$. An aliquot of the solution was poured into a polypropylene test tube for measurement. Calibration standards, verification standards, and re-agent blanks were included in the sample sequence. The values of the major and minor oxides and trace elements were determined by X-ray fluorescence (XRF) and inductively coupled plasma emission spectrometry (ICP-ES). Rare earth element (REE) contents were determined by the inductively coupled plasma mass spectrometry (ICP-MS). Loss on ignition (LOI) was determined by the weight loss of $1 \mathrm{~g}$ sample after heating at $950^{\circ} \mathrm{C}$ for $90 \mathrm{~min}$. Additionally, the geochemical data were evaluated by correlation coefficient analysis, elemental ratios, and mass change calculations. The geochemical results are provided in Appendicies 1 and $2^{*}$.

\section{CHEMICAL CLASSIFICATION}

The Arbat plutonic rocks (in the eastern Miandoab) were classified using the total alkalis $\mathrm{SiO}_{2}$ (wt.\%) vs $\left(\mathrm{K}_{2} \mathrm{O}+\mathrm{Na}_{2} \mathrm{O}\right.$ wt.\%) diagram of Middlemost (1994; Fig. 4A). The mafic rocks were plotted in a wide range represented by gabbro to monzogabbro and monzodiorite fields, in accordance with their petrographic features. The felsic rocks were plotted in monzonite, quartz monzonite and syenite fields, in agreement with their petrographic characteristics. All Arbat plutonic rocks lay within shoshonite-ultrapotassic to alkaline fields defined by Peccerillo and Tylor (1976; Fig. 4B) and Müller et al. (1992; Fig. 4C), and Middlemost (1994; Fig. 4A). These plutonic rocks display low to high potassic affinity with the $\mathrm{K}_{2} \mathrm{O} / \mathrm{Na}_{2} \mathrm{O}$ ratios ranging from 0.6 to 1.9 (Appendix 1 ). The felsic rocks show affinity with metaluminous to weakly peraluminous rocks in the diagram of Shand (1927; Fig. 4D).

\section{GEOCHEMISTRY}

The study samples had a wide range of major and minor elements trends vs $\mathrm{SiO}_{2}$ (Harker, 1909): $\mathrm{SiO}_{2}$ (48-69 wt.\%), $\mathrm{Al}_{2} \mathrm{O}_{3}$ (12-20 wt.\%), $\mathrm{Fe}_{2} \mathrm{O}_{3}$ (2-11 wt.\%), $\mathrm{MgO}$ (0.2-12 wt.\%), $\mathrm{CaO}$ (0.6-10 wt.\%), $\mathrm{K}_{2} \mathrm{O}$ (1.4-8.2 wt.\%), Co, V, Sc, Ba, Sr, Rb, $\mathrm{Th}, \mathrm{Zr}, \mathrm{Nb}, \mathrm{Y}$, and REE (rare earth elements), from mafic to felsic rocks (Appendicies 1-3).

Decreasing trends of $\mathrm{FeO}^{*}, \mathrm{MgO}$ and $\mathrm{MnO}$ oxides, and of $\mathrm{Co}, \mathrm{Ni}, \mathrm{Sc}$, and $\mathrm{V}$ with increasing silica reflected the contribution of these elements to the structure of ferromagnesian minerals, such as olivine, clinopyroxene, biotite, titanite, and iron oxides in mafic units during the early stages of magmatic crystallization. The increasing and then decreasing trends of $\mathrm{TiO}_{2}$ oxide and $Y$ appeared in the contributions of the oxide in the structure of ferromagnesian minerals, such as biotite and titanite, in the intermediate units. The low levels of the oxide in the mafic and felsic units could be due to the low abundances of the minerals. The downward trend of $\mathrm{CaO}$ could be due to its participation in the building of clinopyroxene and Ca-rich plagioclase in rocks with a more basic property. The increasing and then decreasing trend of $\mathrm{Al}_{2} \mathrm{O}_{3}$ demonstrated also that plagioclase and alkali feldspar were the important accumulation phases during the formation of the intermediate units. The increasing trends of $\mathrm{K}_{2} \mathrm{O}$ and $\mathrm{Na}_{2} \mathrm{O}$ oxides, and $\mathrm{Ba}, \mathrm{Rb}, \mathrm{Th}, \mathrm{Nb}, \mathrm{Hf}$, and REE with enhancing silica exhibited the contribution of these elements to the structure of felsic minerals, such as alkali feldspar and biotite, and the accessory minerals, such as zircon, apatite, and titanite, in the felsic units during the late stages of magmatic crystallization. The high relative values of $\mathrm{K}_{2} \mathrm{O}$ and $\mathrm{Na}_{2} \mathrm{O}$ in the mafic rocks were the result of the high modal percentages of alkali feldspar and biotite. These variations in the oxides and elements indicated that fractional crystallization was an important 

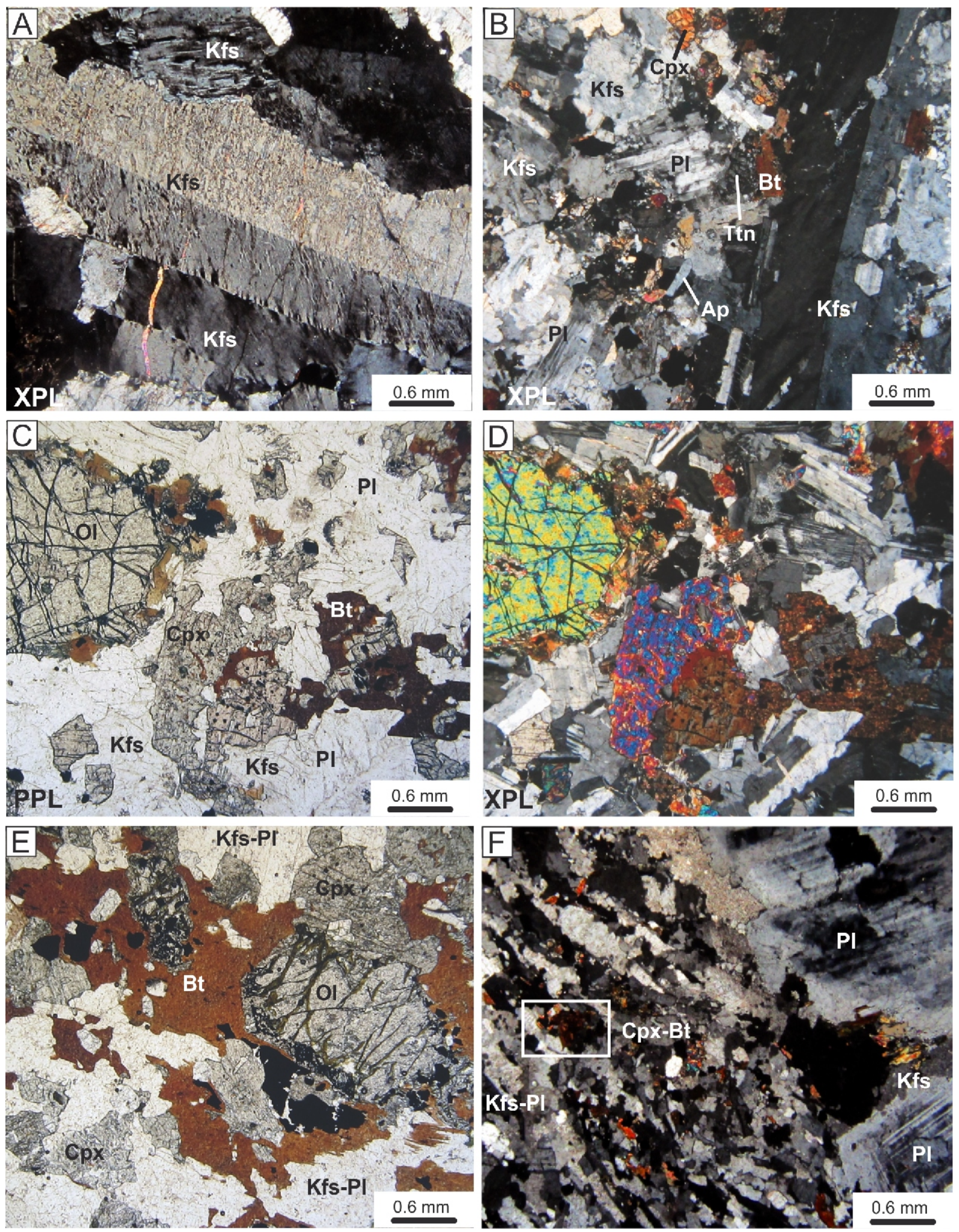

Fig. 3. Microscopic images of syenitic to gabbroic outcrops, eastern Miandoab

A - alkali syenite with large alkali feldspar minerals; B - monzonite with large alkali feldspar minerals and clinopyroxene, biotite, plagioclase, alkali feldspar, titanite and apatite minerals; C, D - monzogabbro with abundant crystals of olivine and clinopyroxene; E - monzogabbro with abundant crystals of biotite, olivine and clinopyroxene along with plagioclase, alkali feldspar, and opaque minerals; $\mathbf{F}$ - the boundary of fine-grained cognate enclave (containing plagioclase, alkali feldspar, clinopyroxene, and biotite minerals) with monzonite; abbreviations after Kretz (1983): Ap - apatite, Bt - biotite, Cpx clinopyroxene, Kfs - K-feldspar, Ol - olivine, PI - plagioclase feldspar, Ttn - titanite 

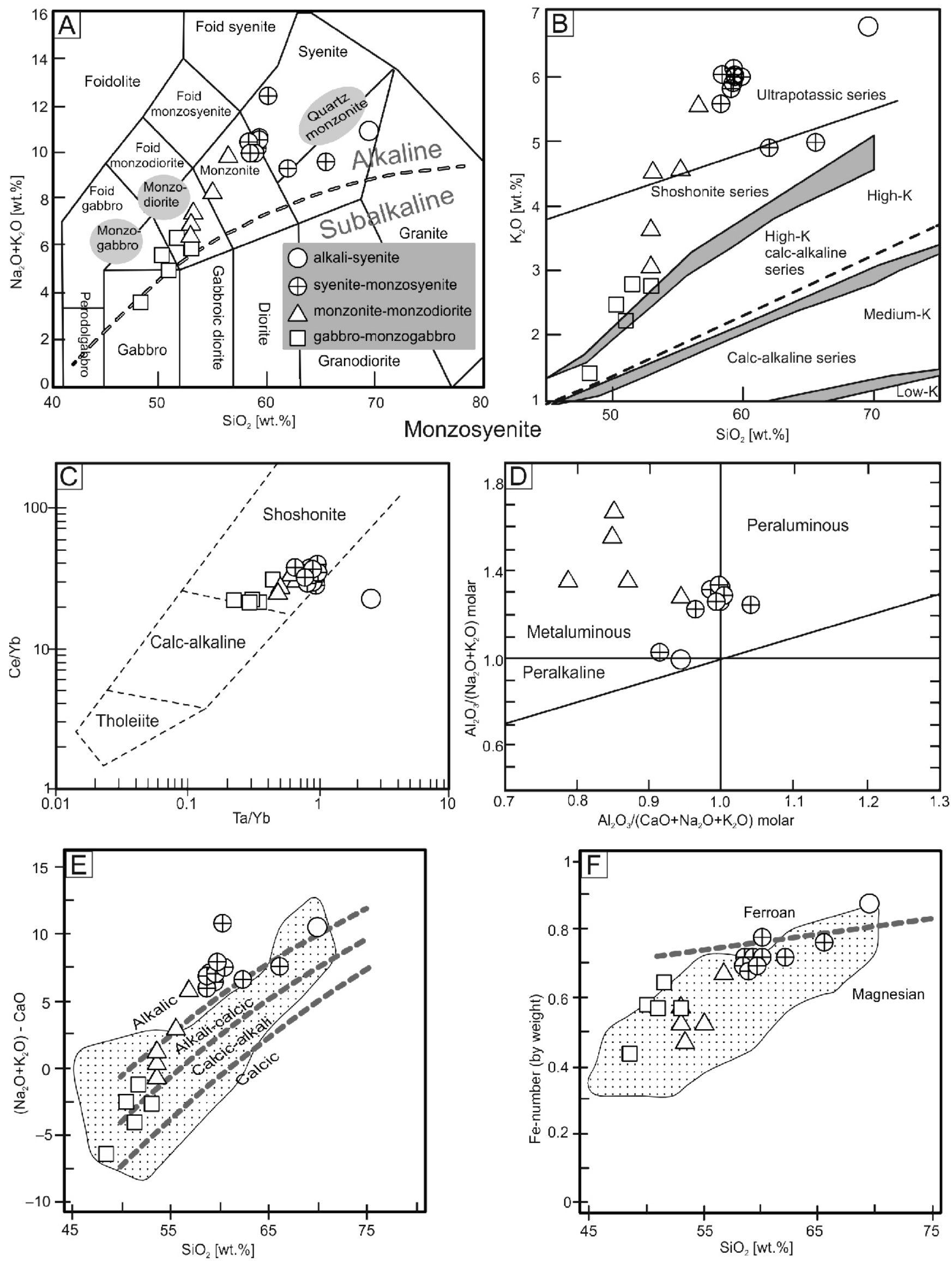

Fig. 4. Descriptive diagrams for determining the nature and classification of the Arbat intrusions, east of Miandoab

A - silica oxide vs total alkaline oxide diagram (Middlemost, 1994); B - silica oxide vs potassium oxide diagram (Peccerillo and Tylor, 1976), discriminant line between shoshonitic and alkali potassic suites is after Calanchi et al. (2002); C - Ce/Yb vs Ta/Yb diagram (Müller et al., 1992); D - discrimination diagram of aluminum changes (A/NK vs A/CNK) based on molar values (Shand, 1927); $\mathbf{E}-\mathrm{Na}_{2} \mathrm{O}+\mathrm{K}_{2} \mathrm{O}-\mathrm{CaO}$ vs $\mathrm{SiO}_{2}$ diagram after Frost et al. (2001); $\mathbf{F}$ - The $\mathrm{SiO}_{2}$ vs Fe-number (wt.\%) diagram after Frost et al. (2001), spotted fields in (E) and (F) are gabbro, monzonite, syenite and quartz syenite from the Katerina Ring Complex, southern Sinai, Egypt (Moreno et al., 2014, 2016) 
factor in the formation of Arbat intrusions. The different values of $\mathrm{P}_{2} \mathrm{O}_{5}$ were complying with the various modal percentages of apatite.

High field strength elements (HFSE), such as $\mathrm{Nb}, \mathrm{Ta}, \mathrm{Hf}, \mathrm{Zr}$, $\mathrm{P}$ and $\mathrm{Ti}$, large-ion lithophile elements (LILE), such as $\mathrm{Rb}, \mathrm{K}$ and $\mathrm{Cs}$ (except for $\mathrm{Sr}$ and $\mathrm{Ba}$ ), rare earth elements (REEs), and the $(\mathrm{La} / \mathrm{Yb})_{n}$ and $(\mathrm{La} / \mathrm{Sm})_{n}$ ratios were increased from the gabbroic to monzonitic and syenitic rocks (Figs. 5 and 6; Appendix 2). In contrast, the $(\mathrm{Sm} / \mathrm{Yb})_{n}$ ratio was almost constant in all types of rocks. The slightly negative-Eu anomaly was observed in all rock units. This demonstrated that plagioclase might not be an important accumulation phase during the formation of these rocks, or plagioclase was a stable phase at the liquidus of partial melting. Another possibility is that the source rock was poor in this element. However, the low Eu contents in the Arbat intrusive rocks confirmed the last scenario. With a review of the patterns of the decreasing and increasing values of the elements (Figs. 5 and 6), it could be concluded that the origin of all rocks was similar, and the fractional crystallization in the parental magma created a combined variation from gabbro to syenite. The values of $U$ and Th were high in all rocks of the intrusions.

\section{DISCUSSION}

\section{TECTONIC IMPLICATIONS}

In most samples, the HFSE ( $\mathrm{Nb}, \mathrm{Ta}, \mathrm{Zr}$ and $\mathrm{Hf}$ ) along with $\mathrm{P}$ and some LILE (Rb, K and Cs) clearly indicated negative and positive anomalies in comparison with the primitive mantle, respectively (Fig. 5). These anomalies occurred in the subduction zones (e.g., Pearce et al., 1984; Pearce and Peate, 1995; White, 2005; Gill, 2010). The HFSE with very low solubility could not be introduced from the subducted slab to the partial meting situation by the subduction fluids (Brenan et al., 1994; Pearce, 1996; White, 2005). The occurrence of the preserved minerals of the elements, such as rutile, apatite and titanite, and their stability in the melt liquidus at the mantle wedge also could cause negative anomalies in some of the HFSE (Woodhead et al., 1993; White, 2005; Xiong et al., 2005). In addition, the depletion of these elements in the felsic parts could indicate the crust interference in their formation (Swain et al., 2008). Such anomalies could also be seen in the melts created from post-collision environments, where there was a subduction-modified mantle source (Fig. 7) to generate these rocks (Neill et al., 2013, 2015). Therefore, small-volume mafic melts were created as a result of the metasomatized mantle in a post-initial collision or break-off scenario (Fig. 7). The alkaline-shoshonitic-ultrapotassic characteristic of all samples (Fig. 4) complied with the syn- or post-collision tectonic setting. These conditions likely occurred in the mantle wedge of the Neotethys subduction under Central Iran during the last stages of the subduction.

During Oligocene-Miocene times, the end of the Neotethys subduction might have occurred beneath Central Iran in the northwestern part of Iran (Molinaro et al., 2005; Vergés et al., 2011; Shafiei Bafti and Mohajjel, 2015; Azizi et al., 2016; Hassanzadeh and Wernicke, 2016; Fig. 7). Oblique subduction of the Neotethys and tectonic pressure from the Arabian Plate towards the north-east with an angle of about $55^{\circ}$ during and after the collision with Central Iran might have built up shear stresses in the upper crust (McClay et al., 2004). The reduction in the lithostatic pressure of the upper mantle caused the decompressive partial melting in the mantle wedge forming the Arbat mafic melts. The results of this study suggested that a post-initial

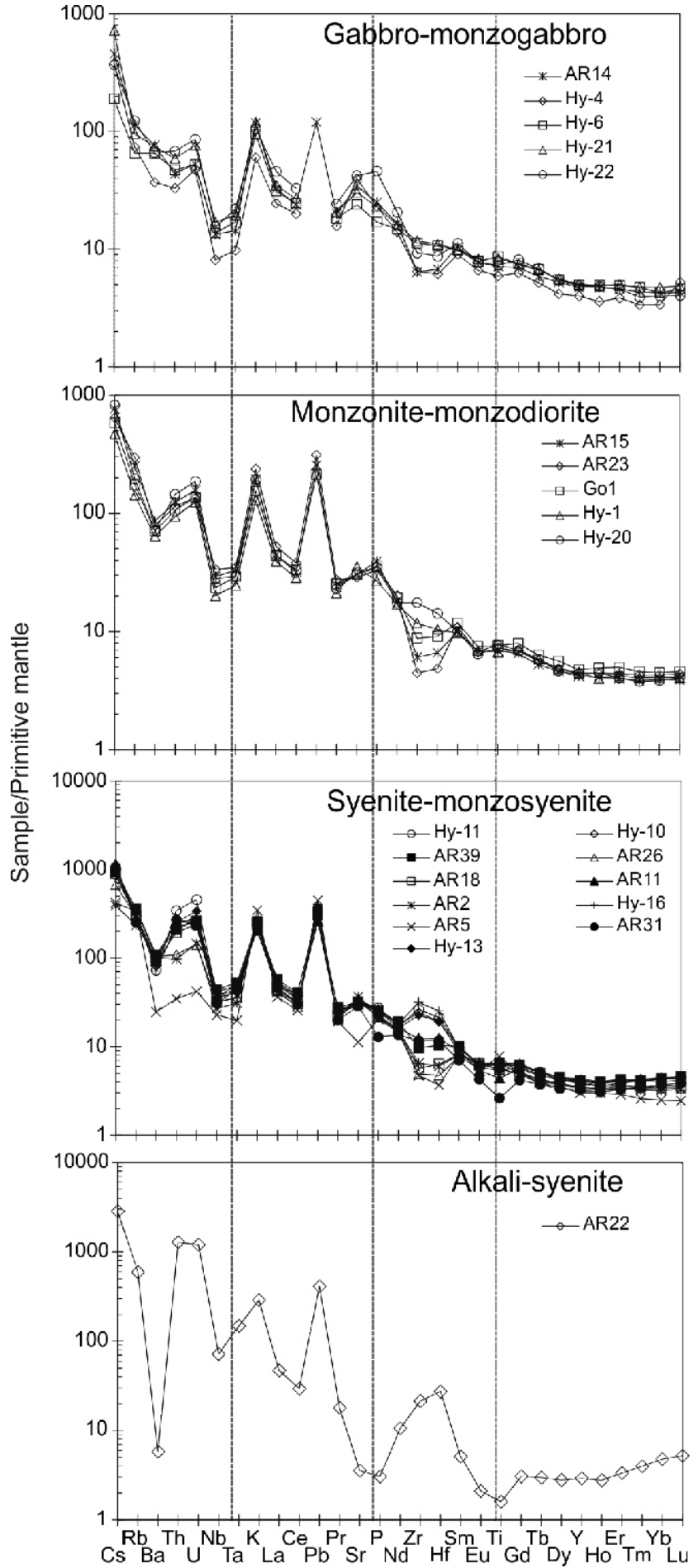

Fig. 5. The multi-element spider diagram normalized to the primitive mantle (Sun and McDonough, 1989) for the Arbat syenite-monzonite-gabbro

collision might have led to the break-off of the Neotethys slab beneath the Arbat continental crust in the Oligocene. Persistence of oblique tectonic stresses caused the right-lateral strike-slip faults, which facilitated the injection of the mafic magmas into the base of the lower crust (Fig. 7). The faults resulted in slab break-off in the remnants of the oceanic crust under the collision zone of the Arabian-Eurasian plates and the decompression melting process in the upwelling mantle due to the formation of the pull-apart basin resulted from the faults. 


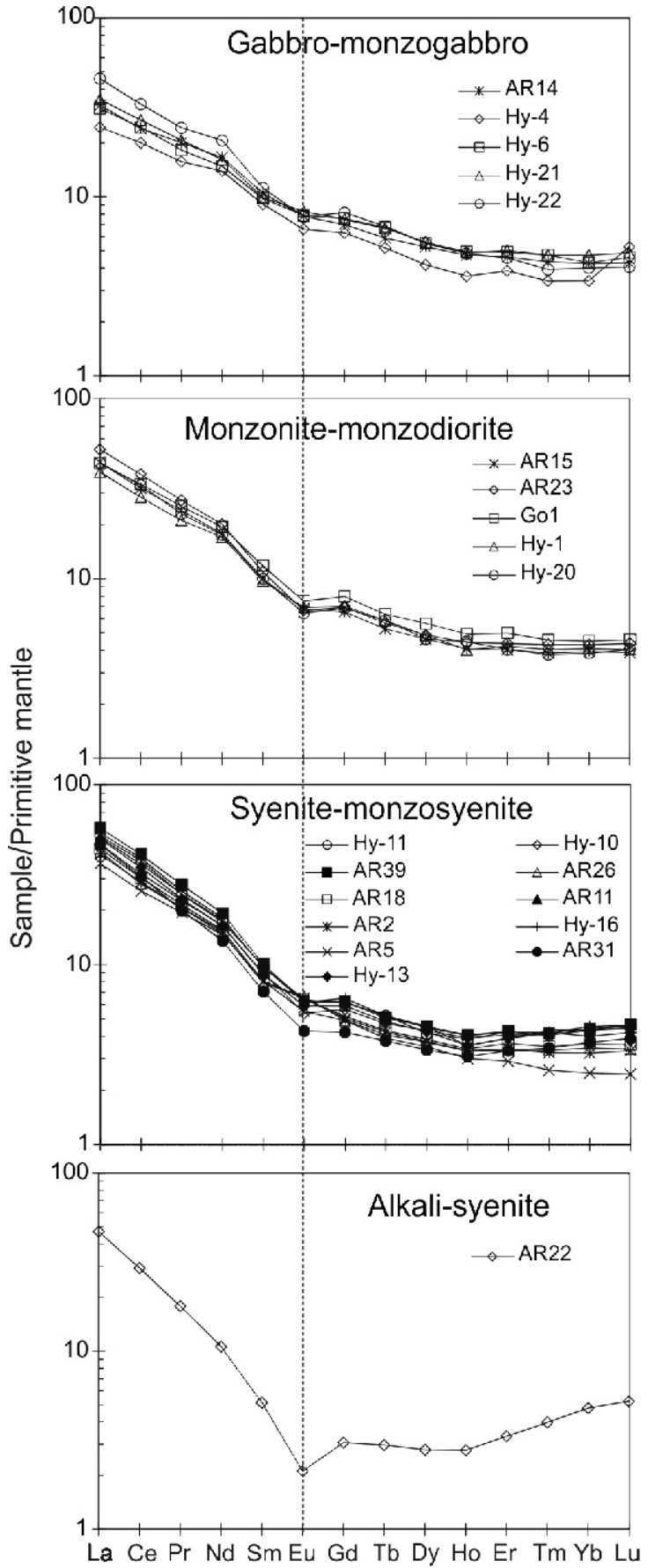

Fig. 6. The REE spider diagrams normalized to the primitive mantle (Sun and McDonough, 1989) for the Arbat syenite-monzonite-gabbro

In order to provide new constraints on the origin and tectonomagmatic evolution of the Arbat intrusions from the UDMA, NW Iran (Appendix 4), we have compared the compositions of syenite-monzonite-gabbro from the Arbat complex to those from post-collisional Ediacaran felsic-mafic rocks in the Katerina Ring Complex (S Sinai, Egypt; Moreno et al., 2014, 2016). Geochemical fields for comparisons in the figure are based on the studies of Moreno et al. (2014, 2016). The comparisons showed that the $\mathrm{Y} / \mathrm{Nb}, \mathrm{Th} / \mathrm{Nb}, \mathrm{Th} / \mathrm{Ta}, \mathrm{La} / \mathrm{Nb}$ and $\mathrm{Ce} / \mathrm{Pb}$ ratios of the Arbat intrusions were mostly similar to those of the continental crust (CC), subduction-related magmatic suites and continental arc (Sub and CA), mafic-felsic rock suites, and continental convergent margin rocks and shoshonites (Sh). In addition, these rock types have, relative to the primitive mantle, negative $\mathrm{Nb}, \mathrm{Ta}, \mathrm{Hf}$ and $\mathrm{Zr}$ anomalies (Fig. 5). These characteristics along with enrichment in LILEs are consistent with a continental arc, syn- or post initial-collision tectonic setting.

\section{MAGMA GENERATION}

The study of many alkaline volcanic and intrusive rocks from NW Iran in the UDMA show that all the rocks occurred and developed in an arc-related setting as a result of the syn-collision or post-collision between the Central Iran and Arabic plates during or after the closure of the Neotethys (Moayyed et al., 2008; Ashrafi et al., 2009; Aghazadeh et al., 2010; Castro et al., 2013; Shafaii Moghadam et al., 2014; Aghazadeh and Badrzadeh, 2015). However, three suggestions can be presented for the origin of the Arbat syenite-monzonite-gabbro from the East Miandoab:

- partial melting in the subducted slab,

- partial melting of the metasomatic mantle wedge in the supra-subduction zone,

- partial melting at the base of the lower continental crust in the supra-subduction zone for the formation of felsic potassic magmas because of the exposure of hot mantle magmas.

There was no high-silica adakite (see Bonin, 2007) in the study area at the same time of the formation of the studied rocks. Therefore, the first scenario could not support the formation of the rocks.

At the time of the collision and after that, the slab break-off occurred (Molinaro et al., 2005; Omrani et al., 2008; Neill et al., 2013, 2015; François et al., 2014a, b; Azizi et al., 2014; Shafaii Moghadam et al., 2014). Slab rollback and then partial delamination could also have occurred (Jahangiri, 2007; Azizi et al., 2014). Post-collisional relaxation process (Aghazadeh et al., 2011; Neill et al., 2015) in the subducted slab at the Oligocene-Miocene might have happened too. Hence, the interference of the subducted slab in the production of subductional fluids and their transportation to the mantle wedge, as well as mantle raising from the slab break-off situation or mantle raising due to the subducted slab rollback, were the melting process factors at the mantle wedge. The gabbroic-monzogabbroic melts were formed in such a condition. Geochemical evidence indicated that these rocks were formed by the partial melting of a mantle spinel Iherzolite in the wedge (Appendix 5). These depths along with the syn-tectonic or post-tectonic conditions indicated that mafic magmas could be formed due to post-collision uplifting; hence, pressure on the partial melting location in the mantle wedge was reduced (decompression melting). This process along with the subductionfluid interference produced from the remnants of subducted slab, the slab break-off in the subducted-slab remnants, and the injection of the deeper parts of the mantle to the mantle wedge resulted in the partial melting (Figs. 7 and $8 \mathrm{~A}$ ) and production of the mafic melt rich in potassium.

Oblique subduction of the Neotethys beneath Central Iran occurred during the Middle Triassic to Middle Cenozoic (McClay et al., 2004; Molinaro et al., 2005; Agard et al., 2011; Alaminia et al., 2013; Azizi et al., 2014; Neill et al., 2015; Hassanzadeh and Wernicke, 2016; Jafari et al., 2018; Fazlnia, $2018 a$, b). These researchers have explained that such subduction caused the formation of the right-lateral strike-slip faults to the crust depths on the western edge of Central Iran (UDMA). In addition, Fazlnia (2018b) suggested that the 


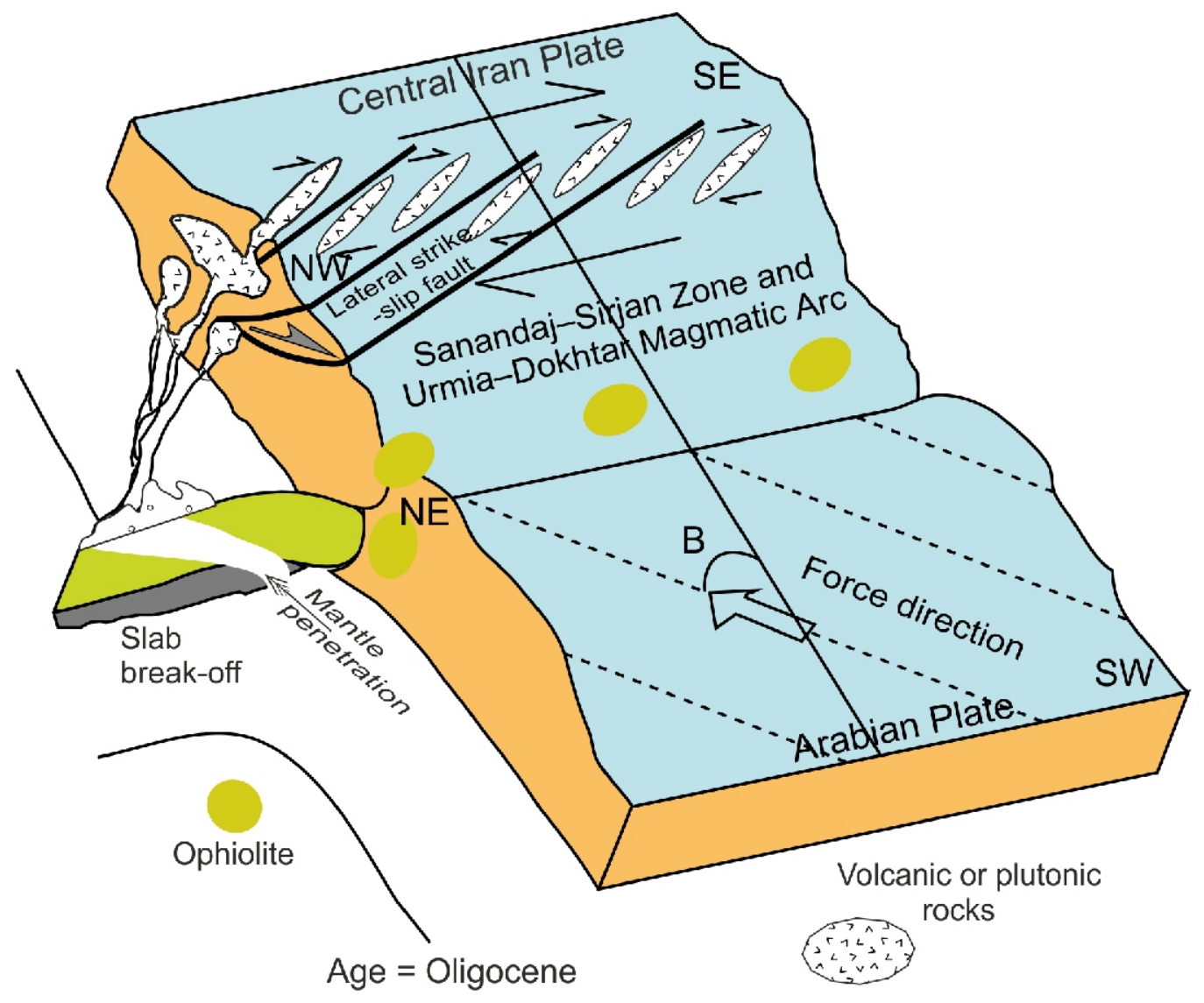

Fig. 7. Tectonomagmatic evolution of the Arbat intrusions

Three dimensional picture of the evolution during Oligocene with the direction of the Arabian Plate towards Central Iran (modified from Fazlnia, 2018b); the fields on the Sanandaj-Sirjan Zone and Urmia-Dokhtar Magmatic Arc are the orientation of the instantaneous strain ellipse

Sardasht mafic and felsic intrusions were formed as a result of the Neotethys slab break-off and transtension along the SE-trending lateral strike-slip fault zones related to the oblique subduction of the Neotethys plate underneath the east SSZ in the Early to Middle Eocene. In addition to this scenario, it is possible that sub-crustal processes, such as lithospheric dripping, could be appropriate for the formation of these rocks. As a result, these faults helped the mantle to uplift in the study area during syn-collision, especially for the post-initial collision of the Central Iran and Arabian plates. Therefore, the pressure reduction process happened properly, leading to partial melting (decompression melting) at the mantle wedge and to the formation of the mafic melt rich in potassium.

\section{EVOLUTION OF MAGMATIC PROCESSES}

The mafic melts probably resulted from a partial melting process of a mantle spinel lherzolite in the wedge (Appendix 5). The ultrapotassic-shoshonite-alkaline characteristics of the Arbat gabbro-monzogabbro samples (Fig. 4A-C) indicated that the melts had resulted from the low percentages of the partial melting of the mantle source. After the melting of the mantle, the melts were separated from that and injected into the crustal magma chambers. Potassium-rich intermediate and felsic rocks in the chambers were formed by the fractional crystallization process (Fig. 8B). At these crustal magma chambers, the fractional crystallization (FC) along with assimilation and fractional crystallization (AFC) might have caused the evolution of the intermediate to felsic parts (Fig. 8C). Geochemical evidence of spider diagrams (Figs. 5 and 6) and Harker variation diagrams (Appendix 3) displayed the same origin for all rocks. Fractional crystallization was also probably the most important factor in the evolution of the Arbat intrusions. Some paradoxes in the distribution patterns of the elements in some samples resulted probably from the AFC process in the crustal chambers.

The Th/Ta (1.7-8.4), Th/Nb (1.5-18) and $\mathrm{Ce} / \mathrm{Pb}$ $(0.16-0.30)$ ratios in the Arbat syenites supported the negligible involvement of a crustal component in the sources of the rocks (e.g., Moreno et al., 2014, 2016). Therefore, the decreasing and increasing values of the elements, such as HFSE and LILE, were probably due to the influx of fluids associated with subduction. Our data suggested that a syn- or post-collision tectonic setting might have led to the break-off of the Neotethys slab beneath the Arbat active continental collision in the Oligocene. Therefore, it is possible that changes in the Th/ $\mathrm{Nb}$, $\mathrm{Th} / \mathrm{Ta}, \mathrm{La} / \mathrm{Nb}$ and $\mathrm{Ce} / \mathrm{Pb}$ ratios could be due to the penetration of asthenospheric magmas from below the slab break-off to the mantle wedge. Fractional crystallization along with the convection processes in the Arbat magma chambers led to the occurrence of lithological variations in the outcrops of the intrusions and more mafic cognate enclaves (Fig. 2E). Yang et al. (2012), Carvalho et al. (2014), Litvinovsky et al. (2015) and Bao et al. (2016) emphasized that probable parts crystallized earlier, in the next pluses of magma injection or during convective flowes within the magma chamber, were scattered as enclaves. 

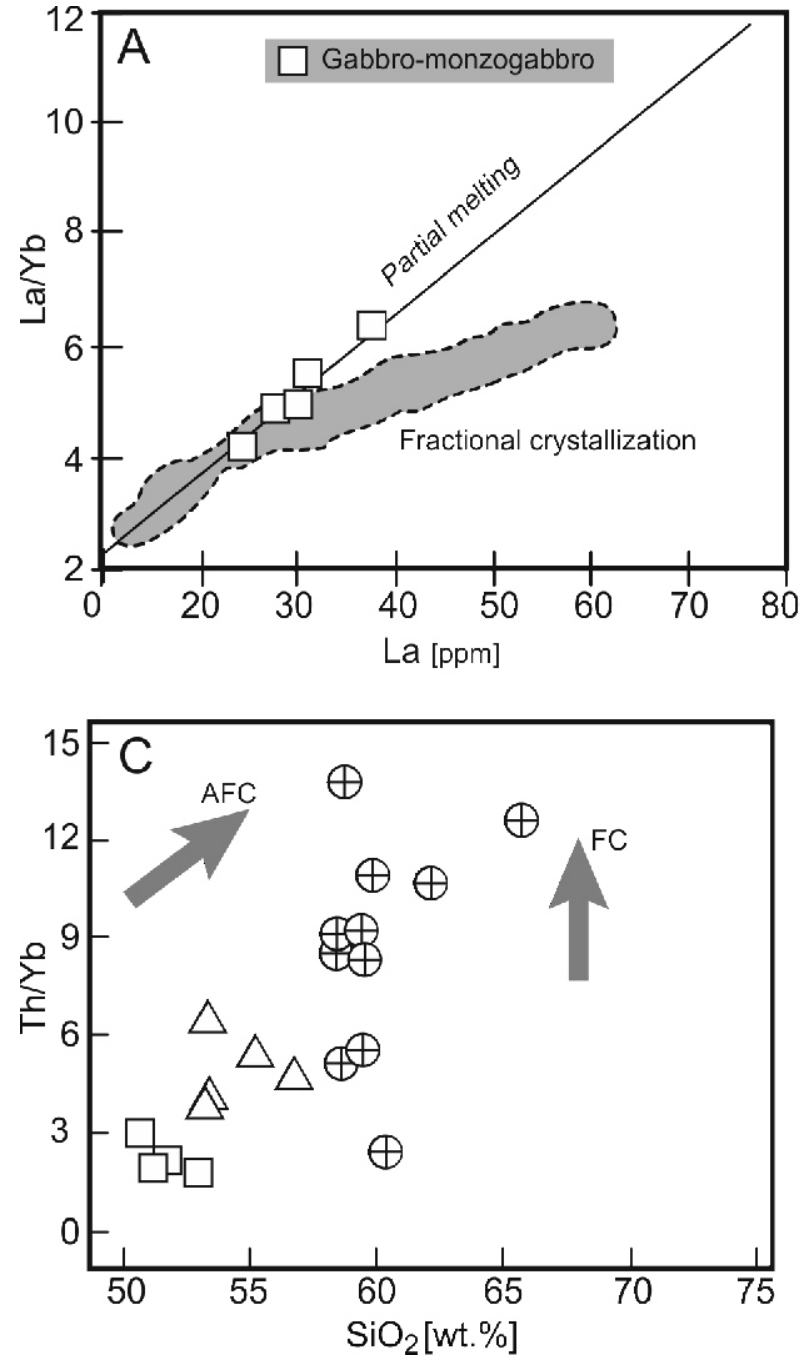

CONCLUSIONS

The Arbat gabbro-monzonite-syenitic complex from the east of Miandoab is metaluminous with alkaline-shoshonite-ultrapotassic characteristics. These rocks were formed in a syn-collision or post-collision arc-related setting in the Oligocene. The intrusions evolved during or after the continental collision at the NW edge of UDMA, Iran. The oblique subduction, closure of Neotethys, and then a continental collision between the Central Iran and Arabian plates caused the evolution of the study area. The mantle wedge beneath the Arbat area endured partial melting and production of the potassium-rich mafic melts as a result of subduction-zone fluids and metasomatic processes, decompression melting due to the ac-

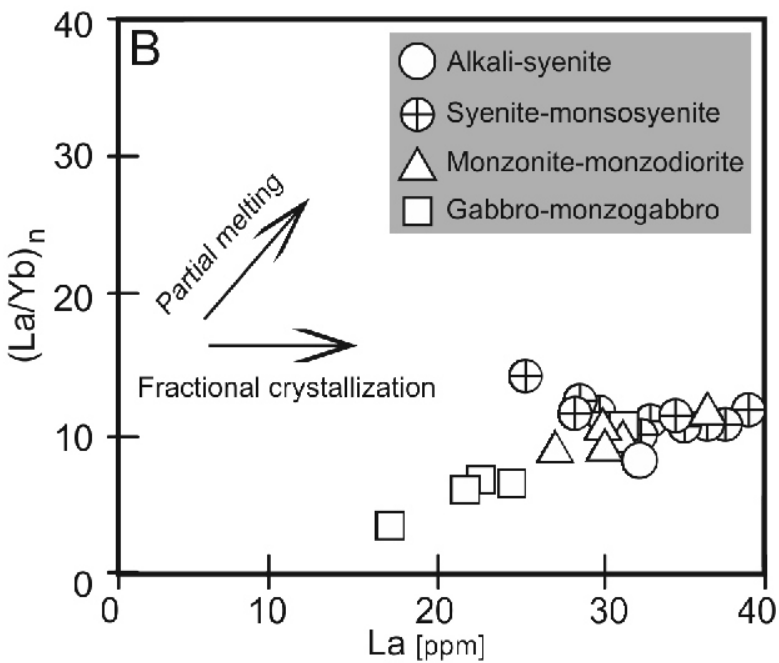

Fig. 8. Geochemical discrimination diagrams to determine crystallization and melting conditions

A - La (ppm) vs La/Sm diagram to determine the partial melting and fractional melting trend according to the trace elements (Chen et al., 2001); B - (La/Yb) ns La (ppm) diagram illustrating the effects of partial melting and fractionation, vectors for FC and PM are from Thirwall et al. (1994); C - the variations of $\mathrm{SiO}_{2}$ vs $\mathrm{Th} / \mathrm{Nb}$ to determine fractional crystallization and assimilation-fractional crystallization trends (Sarrionandia et al., 2012)

tivities of the depth faults, penetration of deep-mantle liquids due to the slab break-off or slab rollback, and/or lithospheric dripping and then partial delamination in the subducted-slab remnants. Therefore, the Arbat mafic melts were probably produced in a subduction-modified mantle source. These mantle wedge magmas endured fractional crystallization (FC process) and, probably, contamination and assimilation (AFC process) to form potassium-rich intermediate and felsic rocks during the injection at the crustal magma chambers.

Acknowledgments. Financial support from the Urmia University (Iran) is gratefully acknowledged. The author thanks the Editors of Geological Quarterly and the Reviewers of the manuscript, Dr. J. Majka and Dr. I. Neill, for their efforts.

\section{REFERENCES}

Agard, P., Omrani, J., Jolivet, L., Whitechurch, H., Vrielynck, B., Spakman, W., Monié, P., Meyer, B., Wortel, R., 2011. Zagros orogeny: a subduction-dominated process. Mineralogical Magazine, 148: 692-725.

Aghazadeh, M., Badrzadeh, Z., 2015. Petrology and petrogenesis of alkaline and calc-alkaline lamprophyres in the NW Iran. Scientific Quarterly Journal, Geosciences, 24: 87-102.
Aghazadeh, M., Castro, A., Rashidnejad Omran, N., Emami, M.H., Moinvaziri, H., Badrzadeh, Z., 2010. The gabbro (shoshonitic)-monzonite-granodiorite association of Khankandi pluton, Alborz Mountains, NW Iran. Journal of Asian Earth Sciences, 38: 199-219.

Aghazadeh, M., Castro, A., Badrzadeh, Z., Vogt, K., 2011 Post-collisional polycyclic plutonism from the Zagros hinterland. 
The Shaivar-Dagh plutonic complex Alborz belt, Iran. Geological Magazine, 148: 980-1008.

Alaminia, Z., Karimpour, M.H., Homan, S.M., Finger, F., 2013 Geochemistry and geochronology of Upper Cretaceous, magnetite series granitoids, Arghash-GhasemAbad, NE Iran. Petrology, 3: 103-118.

Alavi, M., 1994. Tectonic of the Zagros orogenic belt of Iran: new data and interpretations. Tectonophysics, 229: 211-238.

Allen, M.B., Kheirkhah, M., Nill, I., Emami, M.H., Mcleod, C., 2013. Generation of arc and within-plate chemical signatures in collision zone magmatism: Quaternary lavas from Kurdistan province, Iran. Journal of Petrology, 54: 887-911.

Arculus, R.J., Wills, K.J.A., 1980. The petrology of plutonic blocks and inclusions from the Lesser Antilles island arc. Journal of Petrology, 21: 743-799.

Ashrafi, N., Jahangiri, A., Ameri, A., Hasebe, N., Eby, G.N., 2009 Biotite mineral chemistry of the Bozqush and Kaleybar alkaline igneous intrusions, NW Iran. Iranian Society of crystallography and Mineralogy, 17: 381-394.

Azizi, H., Asahara, Y., Tsuboi, M., 2014. Quaternary high-Nb basalts: existence of young oceanic crust under the Sanandaj-Sirjan Zone, NW Iran. International Geology Review, 56: 167-186.

Azizi, H., Mohammadi, K., Asahara, Y., Tsuboid, M., Daneshvare, N., Mehrabi, B., 2016. Strongly peraluminous leucogranite (Ebrahim-Attar granite) as evidence for extensional tectonic regime in the Cretaceous, Sanandaj-Sirjan zone, northwest Iran Chemie der Erde, 76: 529-541.

Babazadeh, S., Ghorbani, M.R., Bröcker, M., D'Antonio, M., Cottle, J., Gebbing, T., Carmine Mazzeo, F., Ahmadi, P., 2017. Late Oligocene-Miocene mantle upwelling and interaction inferred from mantle signatures in gabbroic to granitic rocks from the Urumieh-Dokhtar arc, south Ardestan, Iran. International Geology Review, 59: 1590-1608.

Bacon, C.R., Sisson, T.W., Mazdab, F.K., 2007. Young cumulate complex beneath Veniaminof caldera, Aleutian arc, dated by zircon in erupted plutonic blocks. Geology, 35: 491-494.

Bailey, J.C., Sørensen, H., Andersen, T., Kogarko, L.N., Rose-Hansen, J., 2006. On the origin of microrhythmic layering in arfvedsonite lujavrite from the llímaussaq alkaline complex, South Greenland. Lithos, 91: 301-318.

Bao, Z., Li, C., Zhao, Z., 2016. Metallogeny of the syenite-related Dongping gold deposit in the northern part of the North China Craton: a review and synthesis. Ore Geology Reviews, 73 198-210.

Beard, J.S., Borgia, A., 1989. Temporal variation of mineralogy and petrology in cognate gabbroic enclaves at Arenal Volcano, Costa Rica. Contributions to Mineralogy and Petrology, 103 110-122.

Berberian, F., Berberian, M., 1981. Tectono-Plutonic episodes in Iran. Geological Survey of Iran, Report, 52: 566-593.

Berberian, M., King, G.C.P., 1981. Towards a paleogeography and Tectonic evolution of Iran. Canadian Journal of Sciences, 20: 163-183.

Bonin, B., 2007. A-type granites and related rocks: evolution of a concept, problems and prospects. Lithos, 97: 1-29.

Brenan, J.M., Shaw, H.F., Phinney, D.L., Ryerson, F.J., 1994 Rutileaqueous fluid partitioning of $\mathrm{Nb}, \mathrm{Ta}, \mathrm{Hf}, \mathrm{Zr}, \mathrm{U}$ and Th: implications for high field strength element depletions in island-arc basalts. Earth and Planetary Science Letters, 128: 327-339.

Calanchi, N., Peccerillo, A., Tranne, C.A., Lucchini, F., Rossi, P.L., Kempton, P., Barbieri, M., Wu, T.W., 2002. Petrology and geochemistry of volcanic rocks from the island of Panarea: implications for mantle evolution beneath the Aeolian island arc (southern Tyrrhenian Sea). Journal of Volcanology and Geothermal Research, 115: 367-395.

Carvalho, B.B., Janasi, V. de A., Henrique-Pinto, R., 2014. Geochemical and $\mathrm{Sr}-\mathrm{Nd}-\mathrm{Pb}$ isotope constraints on the petrogenesis of the K-rich Pedra Branca Syenite: implications for the Neoproterozoic post-collisional magmatism in SE Brazil. Lithos, 205: $39-59$.
Castro, A., Aghazadeh, M., Badrzadeh, Z., Chichorro, M., 2013. Late Eocene-Oligocene post-collisional monzonitic intrusions from the Alborz magmatic belt, NW Iran. An example of monzonite magma generation from a metasomatized mantle source. Lithos, 180-181: 109-127.

Chen, C.-H., Chung, S.-H., Hwang, H.-H., Chen, C.-H., Chung, S.L., 2001. Petrology and geochemistry of Neogene continental basalts and related rocks in northern Taiwan (III): alkali basalts and tholeiites from Shiting-Yinko area. Western Pacific Earth Sciences, 1: 19-46.

Conrad, W.K., Kay, R.W., 1984. Ultramafic and mafic inclusions from Adak Island: crystallization history, and implications for the nature of primary magmas and crustal evolution in the Aleutian Arc. Journal of Petrology, 25: 88-125.

Didier, J., Barbarin, B., 1991. Enclaves and Granite Petrology. Developments in Petrology (Book 13). Elsevier Science.

FazInia, A.N., 2017. The evolution of arc magmatism related to Palaeotethys in the west of Salmas, north of the Sanandaj-Sirjan Zone, Iran. Geological Quarterly, 61 (1): 124-137.

FazInia, A.N., 2018a. Geochemistry and tectonic set ting of the Chah-Bazargan sub-volcanic mafic dykes, south Sanandaj-Sirjan Zone (SSZ), Iran. Geological Quarterly, 62 (2): 447-458.

FazInia, A.N., 2018b. Petrogenesis and tectonic significance of Sardasht syenite-monzonite-gabbro-appinite intrusions, NW Iran. International Journal of Earth Sciences, 108: 49-66.

FazInia, A.N., Alizade, A., 2013. Petrology and geochemistry of the Mamakan gabbroic intrusions, Urumieh (Urmia), Iran: magmatic development of an intra-oceanic arc. Periodico di Mineralogia, 82: 263-290.

Ferdowsi, R., Moayyed, M., Kamali, A., 2015. Investigation of petrography, petrogenesis and geochemical features of Kalaibar nepheline syenitic body, Kalaibar, East Azarbaijan. Scientific Quarterly Journal, Geosciences, 24: 29-40.

François, T., Agard, P., Bernet, M., Meyer, B., Chung, S.-L., Zarrinkoub, M.H., Burov, E., Monié, P., 2014a. Cenozoic exhumation of the internal Zagros: first constraints from lowtemperature thermochronology and implications for the build-up of the Iranian plateau. Lithos, 206-207: 100-112.

François, T., Burov, E., Agard, P., Meyer, B., 2014b. Buildup of a dynamically supported orogenic plateau: numerical modeling of the Zagros/Central Iran case study. Geochemistry, Geophysics, Geosystems, 15: 2632-2654.

Frost, B.R., Barnes, C.G., Collins, W.J., Arculus, R.J., Ellis, D.J., Frost, C.D., 2001. A geochemical classification for granitic rocks. Journal of Petrology, 42: 2033-2048.

Gill, R., 2010. Igneous Rocks and Processes: a Practical Guide. Malaysia, Wiley-Blackwell.

Green, J.C., 1992. Proterozoic rifts. Developments in Precambrian Geology, 10: 97-149.

Gualda, G.A.R., Vlach, S.R.V., 2007. The Serra da Graciosa A-type granites and syenites, southern Brazil, Part 3: magmatic evolution and post-magmatic breakdown of amphiboles of the alkaline association. Lithos, 93: 328-339.

Haldar, S.K., Tišljar, J., 2014. Introduction to Mineralogy and Petrology. Amsterdam, Elsevier.

Harker, A., 1909. The Natural History of Igneous Rocks, first ed. London, Methuen London.

Hassanzadeh, J., Wernicke, B.P., 2016. The Neotethyan Sanandaj-Sirjan Zone of Iran as an archetype for passive margin-arc transitions. Tectonics, 35: 586-621.

Jafari, A., FazInia, A.N., Jamei, S., 2015. Mafic enclaves in north of Urumieh plutonic complex: evidence of magma mixing and mingling, Sanandaj-Sirjan zone, NW Iran. Arabian Journal of Geosciences, 8: 7191-7206.

Jafari, A., FazInia, A.N., Jamei, S., 2018. Geochemistry, petrology and geodynamic setting of the Urumieh plutonic complex, Sanandaje-Sirjan Zone, NW Iran: new implication for Arabian and Central Iranian plate collision. Journal of African Earth Sciences, 139: 421-439.

Jahangiri, A., 2007. Post-collisional Miocene adakitic volcanism in NW Iran: geochemical and geodynamic implications. Journal of Asian Earth Sciences, 30: 433-447. 
Keskin, M., 2005. Domal uplift and volcanism in a collision zone without a mantle plume: evidence from Eastern Anatolia. www.MantlePlumes.org

Kheirkhah, M., Allen, M.B., Emami, M., 2009. Quaternary syn-collision magmatism from the Iran/Turkey borderlands. Journal of Volcanology and Geothermal Research, 182: 1-12.

Kogarko, L.N., Williams, C.T., Woolley, A.R., 2006. Compositional evolution and cryptic variation in pyroxenes of the peralkaline Lovozero intrusion, Kola Peninsula, Russia. Mineralogical Magazine, 70: 347-359.

Kretz, R., 1983. Symbols for rock-forming minerals. American Mineralogist, 68: 277-279

Litvinovsky, B.A., Jahn, B.M., Eyal, M., 2015. Mantle-derived sources of syenites from the A-type igneous suites-new approach to the provenance of alkaline silicic magmas. Lithos, 232: 242-265.

McClay, K.R., Whitehouse, P.S., Dooley, T., Richards, M., 2004 3D evolution of fold and thrust belts formed by oblique convergence. Marine and Petroleum Geology, 21: 857-877.

McDonough, W.F., Sun, S.S., 1995. The composition of the Earth. Chemical Geology, 120: 223-253.

McInnes, B.I.A., Evans, N.J., Belousova, E., Griffin, W.L., 2003. Porphyry copper deposits of the Kerman belt, Iran: timing of mineralization and exhumation processes. CSIRO Scientific Research and Reports: 41

McQuarrie, N., van Hinsbergen, D.J.J., 2013. Retrodeforming the Arabia-Eurasia collision zone: Age of collision versus magnitude of continental subduction. Geology, 41: 315-318.

Middlemost, E.A.K., 1994. Naming materials in the magma/igneous rock system. Earth-Science Reviews, 37: 215-224.

Moayyed, M., Moazzen, M., Calagari, A.A., Jahangiri, A., Modjarrad, M., 2008. Geochemistry and petrogenesis of lamprophyric dykes and the associated rocks from Eslamy peninsula, NW Iran: implications for deep-mantle metasomatism. Chemie der Erde, 68: 141-154.

Molinaro, M., Zeyen, H., Laurencin, X., 2005. Lithospheric structure beneath the south-eastern Zagros Mountains, Iran recent slab break-Mountains, Iran recent slab break-off. Terra Nova 17: $1-6$.

Moreno, J.A., Molina, J.F., Montero, P., Abu Anbar, M., Scarrow, J.H., Cambeses, A., Bea, F., 2014. Unraveling sources of A-type magmas in juvenile continental crust: constraints from compositionally diverse Ediacaran post-collisional granitoids in the Katerina Ring Complex, southern Sinai, Egypt. Lithos, 192-195: 56-85.

Moreno, J.A., Molina, J.F., Montero, P., Abu Anbar, M., Scarrow, J.H., Cambeses, A., Bea, F., 2016. Th-REE- and Nb-Ta-accessory minerals in post-collisional Ediacaran felsic rocks from the Katerina Ring Complex (S. Sinai, Egypt): an assessment for the fractionation of $\mathrm{Y} / \mathrm{Nb}$, Th/ $\mathrm{Nb}, \mathrm{La} / \mathrm{Nb}$ and $\mathrm{Ce} / \mathrm{Pb}$ in highly evolved A-type granites. Lithos, 258-259: 173-196.

Müller, D., Rock, N.M.S., Groves, D.I., 1992. Geochemical discrimination between shoshonitic and potassic volcanic rocks in different tectonic settings. Mineralogy and Petrology, 94: 259-289.

Murphy, J.B., 2013. Appinite Suites: a record of the role of water in the genesis, transport, emplacement and crystallization of magma. Earth-Science Review, 119: 55-59.

Nabavi, M.H., 1976. Principle of Iran Geology. First ed. Geological Survey of Iran, Iran.

Neill, I., Meliksetian, K., Allen, M.B., Navasardyan, G. Karapetyan, S., 2013. Pliocene-Quaternary volcanic rocks of NW Armenia: magmatism and lithospheric dynamics within an active orogenic plateau. Lithos, 180-181: 200-215.

Neill, I., Meliksetian, K., Allen, M.B., Navasardyan, G., Kuiper, K., 2015. Petrogenesis of mafic collision zone magmatism: the $\mathrm{Ar}$ menian sector of the Turkish-Iranian Plateau. Chemical Geology, 403: 24-41.

Omrani, J., Agard, P.H., Whitechurch, H., Benoit, M., Prouteau Gand Jolivet, L., 2008. Arc magmatism and subduction history beneath the Zagros Mountains, Iran: a new report of adakites and geodynamic consequences. Lithos, 106: 380-398
Pearce, J., 1996. Sources and settings of granitic rocks. Episodes, 19: $120-125$.

Pearce, J.A., Peate, D.W., 1995. Tectonic implications of the composition of volcanic arc magmas. Annual Review of Earth and Planetary Sciences, 23: 251-285.

Pearce, J.A., Harris, N.B.W., Tindle, A.G., 1984. Trace element discrimination diagrams for the tectonic interpretation of granitic rocks. Journal of Petrology, 25: 956-983.

Peccerillo, R., Taylor, S.R., 1976. Geochemistry of Eocene calc-alkaline volcanic rocks from the Kastamonu area, northern Turkey. Contributions to Mineralogy and Petrology, 58: 63-81.

Peters, T.J., Menzies, M., Thirlwall, M., Kyle, P.R., 2008 Zuni-Bandera volcanism, Rio Grande, USA, melt formation in garnet and spinel-facies mantle straddling the asthenospherelithosphere boundary. Lithos, 102: 295-315.

Rasouli, J., Ghorbani, M., Ahadnejad, V., Poli, G., 2016. Calk-alkaline magmatism of Jebal-e-Barez plutonic complex, SE Iran: implication for subduction-related magmatic arc. Arabian Journal of Geosciences, 9: 287-308.

Rezaei, H., Fonoudi, M., Naghizade, R., Eftekhar Nezhad, J., 2009. Geological map of Ghareh-Aghaj, Scale 1:100,000. Geological Survey and Mineral Exploration of Iran.

Sarrionandia, F., Carracedo Sanchez, M., Eguiluz, L., Abalos, B., Rodriguez, J., Pin, C., Gil Ibarguchi, J.I., 2012. Cambrian rift-related magmatism in the Ossa-Morena Zone (Iberian Massif), geochemical and geophysical evidence of Gondwana break-up. Tectonophysics, 570-571: 135-150.

Shafaii Moghadam, H., Ghorbani, G., Zaki Khedr, M., FazInia, A.N., Chiaradia, M., Eyuboglu, Y., Santosh, M., Galindo Francisco, C., Lopez Martinez, M., Gourgaud, A., Arai, S., 2014. Late Miocene K-rich volcanism in the Eslamieh Peninsula (Saray), NW Iran: implications for geodynamic evolution of the Turkish-Iranian High Plateau. Gondwana Research, 26: 1028-1050.

Shafiei Bafti, S., Mohajjel, M., 2015. Structural evidence for slip partitioning and inclined dextral transpression along the SE Sanandaj-Sirjan Zone, Iran. International Journal of Earth Sciences, 104: 587-601.

Shahabpour, J. 2007. Island-arc affinity of the Central Iranian Volcanic Belt. Journal of Asian Earth Sciences, 30: 652-665.

Shand, S.J., 1927. Eruptive Rocks. Wiley-Blackwell, New York.

Shaw, D.M., 1970. Trace element fractionation during anatexis. Geochimica et Cosmochimica Acta, 34: 237-243.

Stöcklin, J., 1968. Structural history and tectonics of Iran: a review. American Association of Petroleum Geologists, 52: 1229-1258.

Sun, S.S., McDonough, W.F., 1989. Chemical and isotopic systematic of oceanic basalts: implications for mantle composition and processes. . Geological Society of London, Special Publication, 42: 313-345.

Swain, G., Barovich, K., Hand, M., Ferris, G., Schwarz, M., 2008. Petrogenesis of the St Peter Suite, southern Australia: arc magmatism and Proterozoic crustal growth of the South Australian Craton. Precambrian Research, 166: 283-296.

Tajbakhsh, G., Emami, M.H., Moinevaziri, H., Rashidnejad Omran, N., 2012. Petrology, geochemistry and tectonomagmatic setting of Kaleybar Intrusion (Eastern Azarbaijan). Scientific Quarterly Journal, Geosciences, 22: 205-224.

Thirwall, M.F., Smith, T.E., Graham, A.M., Theodorou, N., Hollings, P., Davidson, J.P., Arculus, R.D., 1994. High field strength element anomalies in arc lavas: source or processes. Journal of Petrology, 35: 819-838.

Upton, B.G.J., Parsons, I., Emeleus, C.H., Hodson, M.E., 1996. Layered alkaline igneous rocks of the Gardar Province, South Greenland. . Development in Petrology, 15: 331-363.

Upton, B.G.J., Emeleus, C.H., Heaman, L.M., Goodenough K.M., Finch, A.A., 2003. Magmatism of the mid-Proterozoic Gardar Province, South Greenland: chronology, petrogenesis and geological setting. Lithos, 68: 43-65.

Vergés, J., Saura, E., Casciello, E., Fernàndez, M., Villaseñor, A. Jiménez-Munt, I., García-Castellanos, D., 2011. Crustal-scale cross-sections across the NW Zagros belt: implications for the 
Arabian margin reconstruction. Geological Magazine, 148 739-761.

Wang, K., Plank, T., Walker, J.D., Smith, E.I., 2002. A mantle melting profile across the Basin and Range, SW USA. Journal of Geophysical Research, 107: 5-21.

White, W.M., 2005. Geochemistry. New Jersey Wiley-Blackwell.

Woodhead, J., Eggins, S., Gamble, J., 1993. High field strength and transition element systematics in island and back-arc basin basalts: evidence for multi-phase extraction and a depleted mantle wedge. Earth and Planetary Science Letters, 114: 491-504.

Xiong, X.L., Adamb, T.J., Green, T.H., 2005. Rutile stability and rutile/melt HFSE partitioning during partial melting of hydrous basalt: implications for TTG genesis. Chemical Geology, 218: 339-359.

Yang, J.H., Sun, J.F., Zhang, M., Wu, F.Y., Wilde, S.A., 2012 Petrogenesis of silica-saturated and silica-undersaturated syenites in the northern North China Craton related to post-collisional and intraplate extension. Chemical Geology, 328: 149-167.

Yeganehfar, H., Ghorbani, M.R., Shinjo, R., Ghaderi, M., 2013 Magmatic and geodynamic evolution of Urumieh-Dokhtar basic volcanism, Central Iran: major, trace element, isotopic, and geochronologic implications. International Geology Review, 55: 767-786. 